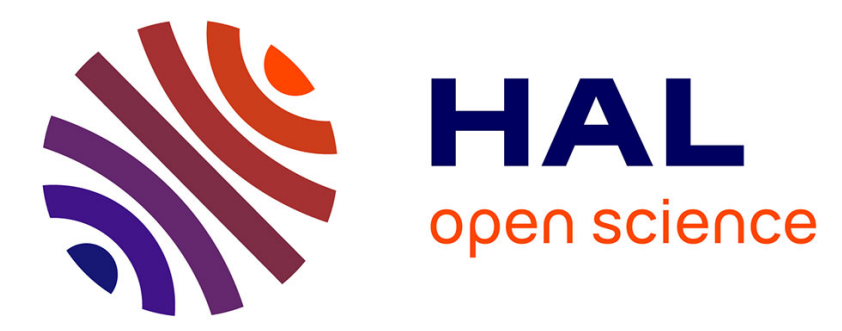

\title{
Gene Expression Analysis by Multiplex Single-Cell RT-PCR
}

\author{
Ludovic Tricoire, Bruno Cauli, Bertrand Lambolez
}

\section{To cite this version:}

Ludovic Tricoire, Bruno Cauli, Bertrand Lambolez. Gene Expression Analysis by Multiplex Single-Cell RT-PCR. Glutamate Receptors, pp.139-154, 2019, 10.1007/978-1-4939-9077-1_10 . hal-03044302

\section{HAL Id: hal-03044302 \\ https://hal.sorbonne-universite.fr/hal-03044302}

Submitted on 7 Dec 2020

HAL is a multi-disciplinary open access archive for the deposit and dissemination of scientific research documents, whether they are published or not. The documents may come from teaching and research institutions in France or abroad, or from public or private research centers.
L'archive ouverte pluridisciplinaire HAL, est destinée au dépôt et à la diffusion de documents scientifiques de niveau recherche, publiés ou non, émanant des établissements d'enseignement et de recherche français ou étrangers, des laboratoires publics ou privés. 


\section{Metadata of the chapter that will be visualized online}

\begin{tabular}{|c|c|c|}
\hline Chapter Title & \multicolumn{2}{|c|}{ Gene Expression Analysis by Multiplex Single-Cell RT-PCR } \\
\hline Copyright Year & \multicolumn{2}{|l|}{2019} \\
\hline Copyright Holder & \multicolumn{2}{|c|}{ Springer Science+Business Media, LLC, part of Springer Nature } \\
\hline \multirow[t]{6}{*}{ Author } & Family Name & Tricoire \\
\hline & Particle & \\
\hline & Given Name & Ludovic \\
\hline & Suffix & \\
\hline & Organization & $\begin{array}{l}\text { Sorbonne Universités, UPMC Univ Paris 06 UM119, Centre } \\
\text { National de la Recherche Scientifique (CNRS) UMR8246, } \\
\text { Institut National de la Santé et de la Recherche Médicale } \\
\text { (INSERM) UMRS1130, Neuroscience Paris Seine,Institut } \\
\text { de Biologie Paris-Seine }\end{array}$ \\
\hline & Address & Paris, France \\
\hline \multirow[t]{6}{*}{ Author } & Family Name & Cauli \\
\hline & Particle & \\
\hline & Given Name & Bruno \\
\hline & Suffix & \\
\hline & Organization & $\begin{array}{l}\text { Sorbonne Universités, UPMC Univ Paris } 06 \text { UM119, Centre } \\
\text { National de la Recherche Scientifique (CNRS) UMR8246, } \\
\text { Institut National de la Santé et de la Recherche Médicale } \\
\text { (INSERM) UMRS1130, Neuroscience Paris Seine,Institut } \\
\text { de Biologie Paris-Seine }\end{array}$ \\
\hline & Address & Paris, France \\
\hline \multirow[t]{7}{*}{ Corresponding Author } & Family Name & Lambolez \\
\hline & Particle & \\
\hline & Given Name & Bertrand \\
\hline & Suffix & \\
\hline & Organization & $\begin{array}{l}\text { Sorbonne Universités, UPMC Univ Paris 06 UM119, Centre } \\
\text { National de la Recherche Scientifique (CNRS) UMR8246, } \\
\text { Institut National de la Santé et de la Recherche Médicale } \\
\text { (INSERM) UMRS1130, Neuroscience Paris Seine,Institut } \\
\text { de Biologie Paris-Seine }\end{array}$ \\
\hline & Address & Paris, France \\
\hline & Email & bertrand.lambolez@upmc.fr \\
\hline Abstract & \multicolumn{2}{|c|}{$\begin{array}{l}\text { Brain circuit assemblies comprise different cellular subpopulations that } \\
\text { exhibit morphological, electrophysiological, and molecular diversity. } \\
\text { Here we describe a protocol which, combined with whole-cell patch- } \\
\text { clamp recording and morphological reconstruction, allows the } \\
\text { transcriptomic analysis of the recorded cell. This protocol provides } \\
\text { recipes on how to detect simultaneously the expression of } 24 \text { genes/ } \\
\text { markers at the single-cell level using polymerase chain reaction (PCR), }\end{array}$} \\
\hline
\end{tabular}


how to design gene-specific probes, and how to validate them. This technique provides multiplexed expression data that cannot be easily obtained by other approaches such as immunological co-labeling.

Keywords mRNA - cDNA - Cell type - Transcriptome - Electrophysiology

(separated by '-') 


\title{
Chapter 10
}

\section{Gene Expression Analysis by Multiplex Single-Cell RT-PCR}

\section{Ludovic Tricoire, Bruno Cauli, and Bertrand Lambolez}

\begin{abstract}
Brain circuit assemblies comprise different cellular subpopulations that exhibit morphological, electrophys- 5 iological, and molecular diversity. Here we describe a protocol which, combined with whole-cell patch- 6 clamp recording and morphological reconstruction, allows the transcriptomic analysis of the recorded cell. 7 This protocol provides recipes on how to detect simultaneously the expression of 24 genes/markers at the 8 single-cell level using polymerase chain reaction (PCR), how to design gene-specific probes, and how to 9 validate them. This technique provides multiplexed expression data that cannot be easily obtained by other 10 approaches such as immunological co-labeling.

Key words mRNA, cDNA, Cell type, Transcriptome, Electrophysiology

1 Introduction

Figure 1 outlines the general protocol for multiplex single-cell PCR 14 (scPCR). After recording of a cell in the whole-cell configuration of 15 the patch-clamp technique, cell content is collected into the elec- 16 trode and expelled into a test tube. Reagents are then added to 17 perform first-strand complementary DNA (cDNA) synthesis from 18 harvested mRNAs. Following overnight incubation of the reverse 19 transcription (RT) reaction, a PCR is set in the same tube to amplify 20 multiple cDNAs of interest by mixing all different primer pairs. 21 Hence, the procedure is fast and simple because one tube corre- 22 sponds to one cell and few manipulations are required. The purpose 23 of the first PCR round is to increase the numbers of cDNA copies 24 to ensure a reliable aliquoting for subsequent re-amplification. 25 Indeed, primer dimers and nonspecific primer-amplicon interac- 26 tions substantially decrease multiplex PCR amplification efficiency. 27 The first PCR products are re-amplified through a second gene- 28 specific PCR to achieve consistent detection by agarose gel electro- 29 phoresis. Besides flexibility and robustness, a major advantage of 30 scPCR resides in its speed and ease of application, which allows 31 rapid feedback between functional and molecular analyses. These 32 


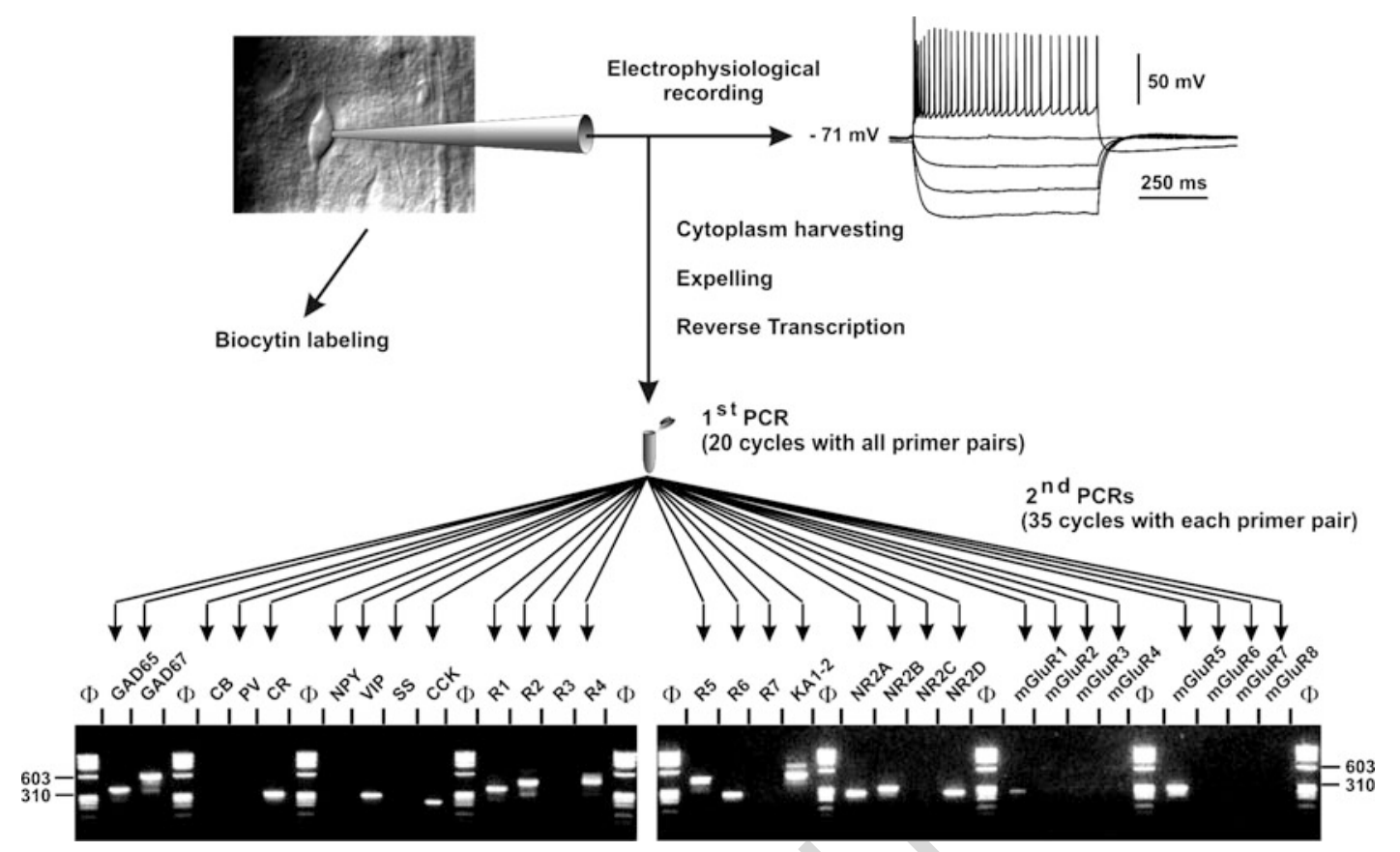

Fig. 1 Gene expression profiling by multiplex scPCR. In the first amplification step, all cDNAs of interest are co-amplified by mixing their specific PCR primers together. PCR products are then individually re-amplified using their specific PCR primers and analyzed by agarose gel electrophoresis. Note that expression of 16 genes was detected in this cortical GABAergic neuron among the 31 genes probed, helping to determine cell-type-specific expression profiles (see [21] for the list of genes analyzed in this cell). During the recording, biocytin present in the intracellular solution diffuses in the neuron and allows post hoc morphological reconstruction

\subsection{Correlating mRNA Expression and Functional Properties of Single Cells}

properties prove essential to establishing correlations between molecular and functional properties at the single-cell level, beyond the large cellular diversity of brain tissues. In parallel with the recording, biocytin included in the intracellular recording solution diffuses throughout and fills the patched cell allowing performing morphological analyses.

The scPCR technique was initially designed to establish correlates between the functional properties of native glutamate receptor channels of the $\alpha$-amino-3-hydroxy-5-methyl-4-isoxazolepropionic acid (AMPA) subtype and their mRNA expression [1]. AMPA receptors are multimeric assemblies of four different subunits GluAl-4 and mediate fast excitatory synaptic transmission in the central nervous system (CNS). Further diversity is generated by alternative splicing and mRNA editing. The initial scPCR report established the reliability and selectivity of this technique by showing that single cerebellar Purkinje neurons expressed a relatively constant set of AMPA receptor subunit mRNAs, which differed from that found in cerebellar granule cells [1]. 
The functional relevance of scPCR analyses was next assessed 51 by demonstrating that the calcium permeability of AMPA receptor 52 is determined by transcriptional control of the expression level of 53 the GluA2 subunit. This was established by showing that the abun- 54 dance of the GluA2 mRNA relative to that of other subunits 55 correlates with the channel properties of native AMPA receptors 56 in different cell types $[2,3]$. Besides its scientific importance, the 57 Jonas et al. [3] study was the first to report scPCR from acute brain 58 slices, which preserve the cytoarchitecture and connectivity of brain 59 tissues.

\subsection{Quantitative} Analyses by SCPCR

1.3 Molecular and Functional Phenotyping of Neuronal Types
Studies of AMPA receptors relied on relative quantification 62 between AMPA receptor subunit mRNAs and their splice and 63 editing variants expressed by single neurons. This was made possi- 64 ble by the fact that a single primer pair co-amplified the four 65 subunit $\mathrm{cDNAs}$ and that their original mRNA ratios were main- 66 tained throughout the whole RT-PCR process $[1,4]$. This relative 67 quantification was performed by using subunit-specific restriction 68 enzymes following amplification with radiolabeled primers [5] or 69 fluorescently labeled primers [6, 7]. This approach has been 70 recently used to quantify the expression ratio of GluDl and 71 GluD2, the two members of the delta family of glutamate 72 receptors [7].

The issue of comparing mRNA expression levels between dif- 74 ferent cells has been further addressed using real-time PCR follow- 75 ing patch-clamp harvesting of the cell's content and RT reaction as 76 described above $[8,9]$. It is noteworthy that in the procedure 77 described by Tricoire et al. [9], the protocol of the first PCR is 78 modified to obtain a linear pre-amplification of the target cDNA. 79 The second PCR step is replaced by a real-time PCR reaction based 80 on TaqMan chemistry (Applied Biosystems). In a single well, the 81 gene-specific amplification is performed at the same time as the 82 amplification as a reference gene allowing normalization. The 83 amplifications of the two genes in a single well are followed on 84 two separate fluorescence channels. Absolute quantification of 85 AMPA receptor subunit $\mathrm{mRNAs}$ expressed by single neurons was 86 performed by introducing just prior to the RT an internal standard 87 consisting in a full-length GluA2 RNA bearing a point mutation 88 [4]. This allowed determining the number of AMPA receptor 89 mRNA copies harvested by patch-clamp, estimating the proportion 90 of AMPA receptor mRNA harvested from single neuron and their 91 respective distribution in somatic versus neuritic compartments. 92

Initially, scPCR was developed to quantify expression of a homolo- 94 gous gene, but then it was extended to the detection of multiple 95 unrelated genes in single cells (as outlined in Fig. 1), aimed at 96 establishing detailed electrophysiological, gene expression, and 97 morphological phenotypes of single neurons [10-12]. This 98 
approach was further used to correlate pharmacological response to the expression of cognate receptors [13-16]. This approach has 99 significantly contributed to establishing the distinctive molecular, 101 functional, and morphological phenotypes of the diverse neuronal 102 types in the cerebral cortex and in the hippocampus [9-11]. Finally, 103 these multivariate phenotypes have been used to classify cortical 104 and hippocampal neuronal types based on unsupervised multipara- 105 metric clustering analyses, hence establishing their statistical signif- 106 icance on a large array of features [9-11, 17, 18]. 107

Recently, studies have reported the development of RNA 108 sequencing on single neurons after whole-cell patch-clamp record- 109 ing $[19,20]$. The entire somatic compartment is aspirated into the 110 recording pipette. After reverse transcription of RNA and cDNA 111 amplification, a sequencing library is prepared. Although this 112 approach appears quite extensive, it is difficult to implement in a 113 classical molecular biology lab and requires high capacity of 114 sequencing and expensive equipment. The protocol described fur- 115 ther is easier to implement and provides results very quickly and 116 does not require complex analysis of the data. We routinely use this 117 protocol to probe expression of 30 or more different genes from 118 single neurons (e.g., [21]). In this chapter, the protocol is given for 119 the simultaneous analysis of 24 genes per cell and is based on a 120 96-well format.

\section{Materials}

\subsection{Reagents (See} Note 1)
1. RNase-free $\mathrm{H}_{2} \mathrm{O}$.

2. RNase-free dithiothreitol (DTT).

3 . Hexamer random primers.

4. Deoxynucleotide (dNTP) solution set. 127

5. Oligonucleotide primers for PCR. Desalted grade (resus- 128 pended at $100 \mu \mathrm{M})$.

6. Recombinant RNase inhibitor (40 units/ $\mu \mathrm{l})$. 130

7. Reverse transcriptase (RT; 200 units $/ \mu \mathrm{l})$. 131

8. Taq DNA polymerase $(5 \mathrm{U} / \mu \mathrm{l})$. 132

9. Agarose. 133

10. $0.5 \times$ Tris-borate-EDTA buffer (TBE). 134

11. DNA ladder. 135

$\begin{array}{lll}2.2 & \text { Equipment } & 137\end{array}$

2. Powder-free gloves. 138

3. 96-well PCR plate suitable for your thermal cycler. 139

4. Adhesive and aluminum seals suitable for the 96-well PCR 140 plate. 
5. Filter tips. Do not stand autoclave. 142

6. $1.5 \mathrm{ml}, 2 \mathrm{ml}$, and $5 \mathrm{ml}$ plastic tubes. 143

7. Homemade expeller. It is made by assembling an old pipette 144 holder with a 10-20 ml syringe. This piece of equipment is 145 used to expel the intracellular solution containing the cytoplas- 146 mic harvest into a clean tube. 147

8. $0.5 \mathrm{ml}$ thin wall PCR tubes. The tubes have to match the size of 148 the wells of the PCR machine used. Given the high efficiency 149 required in each step of the reaction, this point has to be 150 stressed.

9. Programmable thermal cycler.

10. Electrophoresis system suitable for loading with multichannel 153 pipette.

\subsection{Equipment Setup}

\subsection{Reagent Setup for Reverse Transcription}

\subsection{Reagent Setup for PCR}

2.5.1 First $P C R$

Primer Mix
1. Glass pipettes have to be heated to $150-200{ }^{\circ} \mathrm{C}$ for $2 \mathrm{~h}$ to 156 destroy RNase. RNase cannot be inactivated by autoclaving. 157

2. A dedicated workbench space must be set up to prepare the first 158 and second PCR reaction. The plate containing the second 159 PCR reaction should never be brought back on this bench to 160 avoid contamination by PCR DNA. Reverse transcription reac- 161 tion for primer validation must be set up on a different work- 162 bench to avoid contamination by mRNA and cDNA. 163

1. $20 \times$ DTT. A $1 \mathrm{M}$ solution $\left(154 \mathrm{mg}\right.$ in $1 \mathrm{ml} \mathrm{H} \mathrm{H}_{2} \mathrm{O}$ ) is prepared in 165 water and filter sterilized. Working solution $(20 \times)$ is $0.2 \mathrm{M}$ in 166 $\mathrm{H}_{2} \mathrm{O}$ stored as $50 \mu \mathrm{l}$ aliquots in $500 \mu \mathrm{l}$ tubes. 167

2. $5 \times$ RT mix. Stock solution of random hexamer primers is 168 dissolved in TE $\mathrm{pH} 7$ at $3 \mu \mathrm{g} / \mu \mathrm{l}(770 \mu \mathrm{M})$. Each dNTP is 169 supplied as a $100 \mathrm{mM}$ solution. A working RT mix solution 170 $(5 \times)$ of random primers and dNTPs is prepared. For $300 \mu \mathrm{l}: 171$ AU2

This working mix is stored as $21 \mu \mathrm{l}$ aliquots in $500 \mu \mathrm{l}$ tubes at 172 $-80{ }^{\circ} \mathrm{C}$.

3. Reverse transcriptase and RNase inhibitor must be aliquoted 174 $(5 \mu \mathrm{l})$.

4. All these reagents must be stored at $-80^{\circ} \mathrm{C}$ until the day of use 176 and then kept at $-20^{\circ} \mathrm{C}$ during the day. $\quad 177$

1. Make a $50 \times \mathrm{dNTP}(2.5 \mathrm{mM}$ each dATP, dCTP, dGTP, dTTP $) .179$ $20 \mu \mathrm{l}$ of each $100 \mathrm{mM}$ dNTP. $\quad 180$ $720 \mu \mathrm{RNase}$-free $\mathrm{H}_{2} \mathrm{O}$.

Dispense in $100 \mu \mathrm{l}$ aliquots. 182

2. Make PCR primer mix. All primers designed for the first PCR 183 must be mixed to reach a final concentration of $1 \mathrm{pmol} / \mu \mathrm{l} . \quad 184$ In a $5 \mathrm{ml}$ tube, add: 
2.5.2 Second PCR Primer Mix

\subsection{Contamination} Prevention
$832 \mu \mathrm{H}_{2} \mathrm{O}$.

$16 \mu \mathrm{l}$ each primer at $100 \mu \mathrm{M}(48$ primers $=24$ genes $)$.

Dispense in $64 \mu \mathrm{l}$ aliquots, i.e., one aliquot for three cells $(20 \mu \mathrm{l} \quad 188$ per PCR, i.e., 20 pmoles of each primer).

1. Prepare one primer mix for each gene to be analyzed. Primer concentration in this mix is 2 pmoles $/ \mu$ l. 192 From primers stocks at $100 \mu \mathrm{M}$ :

$18 \mu$ primer sense.

$18 \mu \mathrm{l}$ primer antisense.

$864 \mu \mathrm{H} \mathrm{H}_{2} \mathrm{O}$.

2. Transfer primer mixes in a 96 -well plate. The plate consists of 8 rows (labeled from A to $\mathrm{H}$ ) and 12 columns (numbered from 1 to 12 ). The 24 primer mixes must be deposited in 3 columns of 8 wells. For gene \#1, dispense $55 \mu$ l of the primer mix in wells labeled Al, A4, A7, and Al0.

3 . Repeat step 2 with three plates.

4. For gene $\# 2$, repeat steps 2 and 3 by dispensing the corresponding primer mix in wells $\mathrm{Bl}, \mathrm{B} 4, \mathrm{~B} 7$, and $\mathrm{B} 10$.

5. Repeat step 4 for other genes to be analyzed. The four plates should be completely filled with $55 \mu$ l of primer mix in each well. Cover the plates with plastic seal and store them at $-20{ }^{\circ} \mathrm{C}$.

Contamination is of course one main concern when using PCR. In 210 this instance contamination by either RNase or DNA or RNA molecules must be carefully avoided. Although the absence of contamination for a given PCR reaction has to be routinely tested (see below and in the example section), we have found that the observance of a few rules efficiently prevents contamination. RNase 211 212 213 214 215 contamination does not seem to be a major problem, and using standard procedures (see below), contamination, either from reagents, solutions, or labware, can be avoided. At the beginning of the day, the silverware of the recording electrode needs to be rechlorinated with bleach to inactivate possible RNase contamination of the wire.

Contamination by laboratory plasmids is the major problem given the enormous amount of molecules produced (for instance, $1 \mu \mathrm{l}$ of a $1 \mathrm{mg} / \mathrm{ml}$ solution of a $6 \mathrm{~kb}$ plasmid contains 1011 copies of the insert). Our advice is therefore not to set up any of the reactions for single-cell RT-PCR in a room used to manipulate plasmids containing the cDNA to be detected. Even contamination of non-disposable labware by washing is a concern in this case. The same advice is given for in vitro transcripts, although the problem is less critical. 
As a rule we have a set of pipettes especially reserved for single- 231 cell RT-PCR and related preliminary tests. With these pipettes we 232 never manipulate natural RNA or CDNA solutions containing more 233 than $1 \mathrm{ng} / \mu \mathrm{l}$. We never use these pipettes for plasmids or in vitro 234 transcript solutions containing more than $10^{3}$ molecules $/ \mu \mathrm{l}$. In 235 addition, these pipettes are never used either for solutions contain- 236 ing PCR-amplified fragments. Although we worked for 1 year 237 without aerosol-blocking tips and avoided contamination, we 238 now routinely use them. 239

All solutions are kept as aliquots, rather than in stock. 240

Keep in mind that $\mathrm{pH}$ electrodes can be a source of 241 contamination.

We always wear gloves.

Harvesting of mRNA from cells surrounding the target cell or 244 released from dying cells is yet another possible source of contami- 245 nation. Thus it is important to have good quality slices and to 246 include, in the set of gene, one gene that is only express in sur- 247 rounding cells (see Note 2 ).

\subsection{Design of Gene- Specific Primers}

Before starting the design of the primer, you need to collect as 251 much information regarding the structure of your gene of interest 252 such as the presence of introns and whether splice variants have 253 been described in the literature. During the harvesting procedure, 254 it is possible to harvest some genomic DNA. If your gene is intron- 255 less, it is impossible to distinguish amplification from genomic 256 DNA or from mRNA-derived cDNA. Therefore we recommend 257 designing primers on two different exons. You have to make sure of 258 the sequence of your coding sequence and that it is the most 259 updated. As much as possible, use the sequences labeled "reference 260 sequence" in Genbank. You can get this information on the page of 261 your gene of interest in Genbank (http://www.ncbi.nlm.nih.gov/ 262 gene/). This page also indicates the genomic structure of your 263 gene. Usually in reference sequence, the beginning and end of 264 exons are given along with the sequence.

The requirement for designing primers for single-cell RT-PCR 266 is the same as for a basic PCR. The melting temperature should be 267 around $60{ }^{\circ} \mathrm{C}$; the $\% \mathrm{GC}$ should not exceed $60 \%$. They should not 268 form secondary structure such as hairpin, and the two primers 269 should not hybridize to each other. Any program for primer design 270 takes into account these parameters. An example of such program is 271 Primer3 (http://primer3.ut.ee/). The size of the PCR product is 272 typically in the range $200-500 \mathrm{bp}$.

Primers should be specific for your gene of interest and should 274 not significantly recognize other gene sequence. To check the 275 specificity of the designed primers, you can run a nucleotide blast 276 
search (NCBI website) of your sequence against the nucleotide 277 collection of Genbank using the blastn program. Alternatively, 278 you can use the primer-BLAST program of NCBI that designs in 279 a single step the sequence of the primers using primer 3 and run the 280 BLAST against reference sequence database. 281

When possible, it is better if the primers for the second PCR 282 are different from those of the first PCR. The use of internal 283 (nested) primers during the second PCR round enhances amplifi- 284 cation specificity and minimizes the carry-over of primer dimers 285 from the first PCR, improving amplification efficiency and speci- 286 ficity. It increases the confidence in the identity of the PCR prod- 287 uct and further guarantees that you are not amplifying another 288 gene that shares some homology with your gene of interest. 289 Depending on the gene, it is complicated to design two different 290 sets of primers. You can use a common primer for the two PCRs. 291 In the worst-case scenario, the primers can be the same for the 292 two PCRs.

In case your gene is intronless, the approach for the design is 294 the same, but you have to include in your PCR a control reaction 295 intended for the detection of genomic DNA. We routinely probe 296 the presence of the intron of somatostatin gene [15]. After the 297 second PCR, if we obtain a positive result for this intron, we discard 298 the results of intronless genes obtained from the same cell 299 harvesting. 300

3.2 Validation on Total RNA
1. Prepare mRNA from tissue known to express your genes of 302 interest. We routinely prepare total RNAs using Trizol accord- 303 ing to manufacturer instructions. 304

2. Perform reverse transcription in $20 \mu \mathrm{l}$ total volume using 305 reagent provided with the enzyme: 306 $1 \mu \mathrm{g}$ of RNA. $\quad 307$ $4 \mu \mathrm{l} 5 \times$ RT mix. 308

$4 \mu \mathrm{l} 5 \times$ first-strand buffer. 309

1 RNase-free $\mathrm{H}_{2} \mathrm{O}$. $310 \mathrm{AU} 3$

3. Warm at $65^{\circ} \mathrm{C}$ for $5 \mathrm{~min}$ and then cool down on ice for $\mathrm{l} \mathrm{min.} \quad 311$

4. Add: 312

$2 \mu \mathrm{l} 0.1 \mathrm{M}$ DTT. 313

$1 \mu \mathrm{l}$ RNase inhibitor. $\quad 314$

$1 \mu \mathrm{l}$ reverse transcriptase. 315

5. Incubate overnight at $37^{\circ} \mathrm{C}$. 316

6. Dilute cDNA to a final concentration of $\mathrm{lng} / \mu \mathrm{l}$. 317

7. Prepare one PCR reaction per primer pair to test: 318 


\begin{tabular}{|c|c|}
\hline cDNA@1 ng/ $\mu \mathrm{l}$ & $1 \mu \mathrm{l}$ \\
\hline $50 \times$ dNTP mix & $2 \mu \mathrm{l}$ \\
\hline $10 \times$ Taq polymerase buffer & $10 \mu \mathrm{l}$ \\
\hline Taq polymerase $(5 \mathrm{U} / \mu \mathrm{l})$ & $0.5 \mu \mathrm{l}$ \\
\hline RNase-free $\mathrm{H}_{2} \mathrm{O}$ & To $80 \mu \mathrm{l}$ \\
\hline
\end{tabular}

8. Incubate for $1 \mathrm{~min}$ at $95^{\circ} \mathrm{C}$ in the PCR instrument, and then 325 add $20 \mu \mathrm{l}$ of primer mix containing forward and reverse primers 326 in RNase-free $\mathrm{H}_{2} \mathrm{O}$ (primer final concentration: $2 \mathrm{pmol} / \mu \mathrm{l}$ ). $\quad 327$

9. Run PCR program:

\begin{tabular}{lll}
\hline One time: & $95^{\circ} \mathrm{C} / 3 \mathrm{~min}$ & 329 \\
\hline 40 times: & $95^{\circ} \mathrm{C} / 30 \mathrm{~s}$ & 330 \\
& $60^{\circ} \mathrm{C} / 30 \mathrm{~s}$ & \\
& $72^{\circ} \mathrm{C} / 35 \mathrm{~s}$ & \\
\cline { 1 - 2 } & $72^{\circ} \mathrm{C} / 10 \mathrm{~min}$ & 331 \\
\cline { 1 - 2 } One time: & & 332 \\
\hline Then cool down at $15^{\circ} \mathrm{C}$ & 333 \\
\hline
\end{tabular}

10. Analyze your PCR product by agarose gel electrophoresis. You 334 must verify you obtain a single band at the correct size. We 335 routinely run all PCR reactions on $2 \%$ agarose gel in $0.5 \times \mathrm{TBE} 336$ buffer next to a DNA molecular marker.

11. Mix and dilute the primers for the first PCR (48 different 338 primers) at $1 \mathrm{pmol} / \mu \mathrm{l}$ in water. This $\operatorname{mix}$ can be aliquoted 339 and stored at $-20{ }^{\circ} \mathrm{C}$. 340

12. Set up the first PCR reaction:

\begin{tabular}{|c|c|}
\hline $\mathrm{cDNA}$ at $1 \mathrm{ng} / \mu \mathrm{l}$ & $1 \mu \mathrm{l}$ \\
\hline $\mathrm{dNTP}$ at $2.5 \mathrm{mM}$ each & $2 \mu \mathrm{l}$ \\
\hline $10 \times$ Taq polymerase buffer & $10 \mu \mathrm{l}$ \\
\hline Taq polymerase $(5 \mathrm{U} / \mu \mathrm{l})$ & $0.5 \mu \mathrm{l}$ \\
\hline RNase-free $\mathrm{H}_{2} \mathrm{O}$ & To $80 \mu \mathrm{l}$ \\
\hline
\end{tabular}

13. Incubate $1 \mathrm{~min}$ at $95^{\circ} \mathrm{C}$ in the PCR machine, and then add 348 $20 \mu \mathrm{l}$ of first PCR primer mix prepared in Subheading 2.5. 349

14. Run PCR program: 350

\begin{tabular}{lll}
\hline One time: & $95^{\circ} \mathrm{C} / 3 \mathrm{~min}$ & \\
20 times: & $95^{\circ} \mathrm{C} / 30 \mathrm{~s}$ & 352 \\
& $60^{\circ} \mathrm{C} / 30 \mathrm{~s}$ \\
\hline & (continued)
\end{tabular}


One time:

$72{ }^{\circ} \mathrm{C} / 10 \mathrm{~min}$

Then cool down at $15{ }^{\circ} \mathrm{C}$

15. Set up the second PCR.

\begin{tabular}{lll}
\hline & For one gene & Mix for 24 genes $(\times 25)$ \\
\hline RNase-free $\mathrm{H}_{2} \mathrm{O}$ & $75.5 \mu \mathrm{l}$ & $1887.5 \mu \mathrm{l}$ \\
\hline $10 \times$ Taq buffer & $10 \mu \mathrm{l}$ & $250 \mu \mathrm{l}$ \\
\hline $50 \times$ dNTP & $2 \mu \mathrm{l}$ & $50 \mu \mathrm{l}$ \\
\hline First PCR reaction & $2 \mu \mathrm{l}$ & $50 \mu \mathrm{l}$ \\
\hline Taq polymerase $(5 \mathrm{U} / \mu \mathrm{l})$ & $0.5 \mu \mathrm{l}$ & $12.5 \mu \mathrm{l}$ \\
\hline
\end{tabular}

16. Transfer $90 \mu \mathrm{l}$ of the mix in 24 PCR tubes, one per gene to analyze.

17. Add $10 \mu \mathrm{l}$ of gene-specific primer mix in each tube.

18. Run the PCR program:

\begin{tabular}{ll}
\hline One time: & $95^{\circ} \mathrm{C} / 3 \mathrm{~min}$ \\
\hline 35 times: & $95^{\circ} \mathrm{C} / 30 \mathrm{~s}$ \\
& $60^{\circ} \mathrm{C} / 30 \mathrm{~s}$ \\
& $72{ }^{\circ} \mathrm{C} / 35 \mathrm{~s}$ \\
\hline One time: & $72^{\circ} \mathrm{C} / 10 \mathrm{~min}$ \\
\hline Then cool down at $15^{\circ} \mathrm{C}$ & \\
\hline
\end{tabular}

19. Analyze your PCR product by agarose gel electrophoresis. You must verify you obtain a single band of the expected size. In case one or several bands are absent, it indicates that some primers are incompatible, and a new set of primer pairs have to be designed.

20. It is important to perform negative control experiments from time to time to check the absence of contamination (see Note 2 ). This is primarily achieved by running the same protocol as described above using no $\mathrm{RNA}\left(\mathrm{H}_{2} \mathrm{O}\right.$ control). You also have to perform the protocol described in Subheadings 3.4-3.6 using just intracellular recording solution. This step allows you to check the quality of the recording solution.

3.3 Patch-Clamp Harvesting of Single Cells
A key issue in single-cell molecular biology, especially in tissue slices, is to harvest selectively the cellular content without contamination from surrounding cells. The whole-cell configuration of the patch-clamp technique confers a tightly insulated physical and 
electrical access to the cell's cytoplasm. It thus provides ideal means 388 of harvesting in complex tissue following electrophysiological char- 389 acterization. Patch-clamp harvesting of a GABAergic neuron from 390 a slice of rat cerebral cortex is illustrated in Fig. 2 .

The very first step of the single-cell RT-PCR protocol starts 392 with the electrophysiological recording of the neuron to be ana- 393 lyzed. The cell is first visually identified and chosen according to 394 morphological criteria. The patch pipette filled with $8 \mu$ intracellu- 395 lar solution ( see Note $\mathbf{3}$ ) is then advanced toward the neuron with 396 positive pressure in order to avoid contamination by the surround- 397 ing tissue.

Once the pipette reaches the neuron, a gigaohm seal is 399 obtained which ensures a very tight contact between the cell mem- 400 brane and the pipette avoiding the risk of contamination (cell- 401 attached configuration). The patch membrane under the pipette 402 is then broken by applying a brief negative pressure establishing a 403 physical and electrical continuity between the cytoplasm and the 404 pipette solution. At the end of the whole-cell recording, which 405

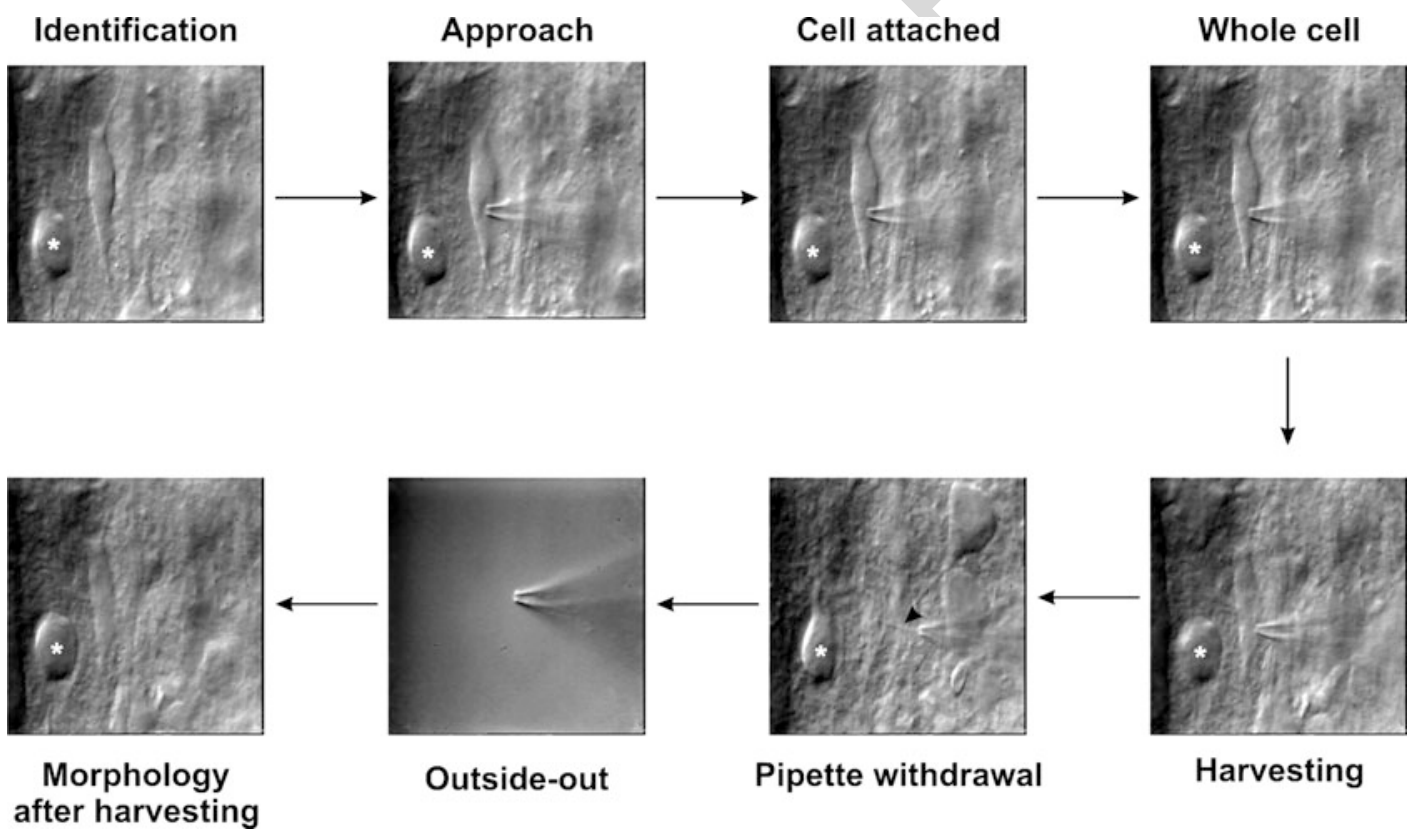

Fig. 2 Patch-clamp harvesting in brain slices. Once a cell is visually identified, the recording pipette is approached with positive pressure in order to avoid cellular debris contamination at the tip of the pipette. Note the dimple on the membrane of this neuron. Positive pressure is then interrupted in order to form a cellattached configuration with a gigaohm tight seal, and subsequently brief suctions allow going into whole-cell configuration. At the end of the recording, the cytoplasm is harvested by applying a gentle negative pressure into the pipette, while the tight seal is maintained. Note the shrinkage of the cell body during the harvesting procedure. The recording pipette is then gently withdrawn to form an outside-out patch, which favors cell membrane closure for subsequent biocytin staining, and preservation of harvested material in the patch pipette 
should not last more than 20 min for RNA preservation, the cell's 406 content is aspirated into the recording pipette by applying negative pressure under electrophysiological and visual control in order to avoid contamination and to ensure a good cytoplasm collection. During the harvesting procedure, a careful (re)positioning of the pipette away from the nucleus (see Note 4), which can obstruct the pipette tip, is sometimes required. In slices, the harvesting procedure is stopped if the gigaohm seal is lost. After the cytoplasm collection, the pipette is gently withdrawn from the neuron to favor the closure of the cell membrane. Ideally, an outside-out configuration is then achieved which allows the preservation of the pipette's content and of the cell.

The electrophysiological control of this harvesting procedure offers several advantages. Firstly, only mRNA from the recorded neuron is harvested with very limited risk of contamination by the tissue surrounding the cell. Secondly, the harvesting procedure allows a good preservation of the collected mRNAs. Thirdly and inherently to the single-cell RT-PCR technique, the analyzed neuron can be electrophysiologically and pharmacologically characterized. Finally, when a diffusible tracer (e.g., biocytin) is added into

3.4 General Protocol for the Single-Cell RT Reaction
1. During the course of the electrophysiological experiments, the 429 aliquots of intracellular solution, $5 \times$ RT mix, and $20 \times$ DTT are 430 kept on ice mix and RNase inhibitor and reverse transcriptase 431 kept at $-20{ }^{\circ} \mathrm{C}$. The patch pipette is filled with $8 \mu$ patch 432 intracellular solution. At the end of the recording, $2 \mu \mathrm{l}$ of $5 \times 433$ RT mix and $0.5 \mu$ of $20 \times$ DTT are pipetted into the RT-PCR 434 tube (0.5 ml PCR tube).

2. After recording and aspirating the cell, the pipette's content is 436 expelled (we usually collect $6.5 \mu \mathrm{l}$ ) in this tube. The tip of the 437 pipette should be broken in order to facilitate the expelling in 438 the PCR tube containing $2 \mu \mathrm{l}$ of $5 \times$ RT mix and $0.5 \mu \mathrm{l} 20 \times 439$ DTT. We then add $0.5 \mu \mathrm{l}$ RNase inhibitor and $0.5 \mu \mathrm{l} \mathrm{RT}$, and 440 the tube is flicked and briefly centrifuged. The final volume 441 should then be roughly $10 \mu$ with final concentrations: 442 $0.5 \mathrm{mM}$ each dNTP, $5 \mu \mathrm{M}$ random primers, $10 \mathrm{mM}$ DTT, 443 and 20 units of RNase inhibitor and 100 units of reverse 444 transcriptase.

3. The RT reaction then proceeds overnight at $37^{\circ} \mathrm{C}$. After this 446 incubation, the tube is kept at $-80{ }^{\circ} \mathrm{C}$ until the PCR reaction. 447

The remainder of the aliquots of $5 \times$ RT mix and $20 \times$ DTT is 448 discarded after each day of experiment. 449 
3.5 First PCR-PCR Multiplex

1. Set up PCR reaction on ice. Amounts can be scaled depending 451 of the number of cells to process.

For one cell/RT reaction

\begin{tabular}{|c|c|}
\hline RNase-free $\mathrm{H}_{2} \mathrm{O}$ & $59.5 \mu \mathrm{l}$ \\
\hline $10 \times$ Taq buffer & $10 \mu \mathrm{l}$ \\
\hline Taq polymerase $(5 \mathrm{U} / \mu \mathrm{l})$ & $0.5 \mu \mathrm{l}$ \\
\hline
\end{tabular}

2. Add $70 \mu \mathrm{l}$ of the mix to each RT tube without touching the 458 content. Change tip for each tube.

3. Incubate $1 \mathrm{~min}$ at $95{ }^{\circ} \mathrm{C}$ in the PCR machine, and then add 460 $20 \mu$ of multiplex primer mix to each tube, one by one. Change 461 tip for each tube.

4. Run PCR program:

\begin{tabular}{lll}
\hline One time: & $95^{\circ} \mathrm{C} / 3 \mathrm{~min}$ & 464 \\
\hline 21 times: & $95^{\circ} \mathrm{C} / 30 \mathrm{~s}$ & 465 \\
& $60^{\circ} \mathrm{C} / 30 \mathrm{~s}$ & \\
& $72^{\circ} \mathrm{C} / 35 \mathrm{~s}$ & \\
\cline { 1 - 2 } & $72^{\circ} \mathrm{C} / 10 \mathrm{~min}$ & 466 \\
\hline One time: & & 467 \\
\hline Then cool down at $15^{\circ} \mathrm{C}$ & & 468 \\
\hline
\end{tabular}

3.6 Second PCR-PCR Simplex
1. Cool down the 96-well PCR plate on ice prior to setting up the 469 PCR reaction ( see Note 5 ).

2. For each cell, prepare the following mix in a $5 \mathrm{ml}$ tube in the 471 order:

\begin{tabular}{|c|c|c|}
\hline & For one gene & Mix for 24 genes $(\times 25)$ \\
\hline RNase-free $\mathrm{H}_{2} \mathrm{O}$ & $75.5 \mu \mathrm{l}$ & $1887.5 \mu \mathrm{l}$ \\
\hline $10 \times$ Taq buffer & $10 \mu \mathrm{l}$ & $250 \mu \mathrm{l}$ \\
\hline dNTP $50 \times(2.5 \mathrm{mM}$ each $)$ & $2 \mu \mathrm{l}$ & $50 \mu \mathrm{l}$ \\
\hline First PCR reaction & $2 \mu \mathrm{l}$ & $50 \mu \mathrm{l}$ \\
\hline Taq polymerase $(5 \mathrm{U} / \mu \mathrm{l})$ & $0.5 \mu \mathrm{l}$ & $12.5 \mu \mathrm{l}$ \\
\hline
\end{tabular}

3. Vortex and then centrifuge for few seconds with a small work- 479 bench centrifuge.

4. Dispense $90 \mu \mathrm{l}$ of the mix in the 96 -well plate. One cell occu- 481 pies three columns of eight wells. One plate is for four cells. 482 Change tip for each cell.

5. Take the plate containing the primers simplex (nested primer) 484 out of the fridge, and centrifuge them for $10 \mathrm{~s}$. Using the 485 multichannel pipette, add $10 \mu \mathrm{l}$ of second PCR primer mix by 486 
following the organization of the second PCR mix plate 487 prepared in Subheading 2.5. 488

6. Cover the plate with aluminum seal; transfer directly the plate 489 from ice to the PCR machine. The block must have been 490 pre-warmed at $94{ }^{\circ} \mathrm{C}$. 491

7. Run PCR program: 492

\begin{tabular}{ll}
\hline One time: & $95^{\circ} \mathrm{C} / 3 \mathrm{~min}$ \\
\hline 35 times: & $95^{\circ} \mathrm{C} / 30 \mathrm{~s}$ \\
& $60^{\circ} \mathrm{C} / 30 \mathrm{~s}$ \\
\hline One time: & $72^{\circ} \mathrm{C} / 35 \mathrm{~s}$ \\
\hline Then cool down at $15{ }^{\circ} \mathrm{C}$ & $72{ }^{\circ} \mathrm{C} / 10 \mathrm{~min}$ \\
\hline
\end{tabular}

8. Analyze your PCR product by agarose gel electrophoresis. You must verify you obtain a single band of the correct size. For loading the agarose gel, use a multichannel pipette different from the one used for loading the second PCR primer mix.

1. Given the high sensitivity of the method and the high risk of contamination, we recommend using the following reagents which have been tested by us and others lab successfully: RNase-free dithiothreitol (Sigma), hexamer random primers (Roche or Life Technologies), deoxynucleotide solution set (New England Biolabs), recombinant RNAsin (Promega), reverse transcriptase SuperScript II (Life Technologies), and Taq DNA polymerase (Qiagen).

2. For each new primer pair or combination of primers, we test mRNA contamination from surrounding tissue by placing a patch-clamp pipette into the slice without establishing a seal. Following removal of the pipette, its content is then processed by RT-PCR. In our hands, this control has always yielded negative results. It must be noted, however, that a better negative control consists in scPCR of cells devoid of the mRNA of interest, from the same biological preparation.

3. Virtually any type of patch-clamp intracellular solution can be used, as long as it does not interfere with RT-PCR efficiency in cell-free assays. In our experience, intracellular solutions containing $\mathrm{K}+$ or $\mathrm{Cs}+$ cations and $\mathrm{Cl}$ - and gluconate or methyl sulfate anions are equally suitable to scPCR. 
4. When expression of intronless genes is analyzed, genomic DNA 524 can be a source of false positives, and avoiding nucleus collec- 525 tion is here essential. We addressed this issue by including a 526 control amplifying an intronic DNA sequence in the scPCR 527 reaction and found that this control efficiently detected geno- 528 mic DNA contamination [16].

5 . In case of scaling down the whole procedure, instead of using 530 96-well format, you can use individual 0.2 or $0.5 \mathrm{ml}$ PCR 531 tubes.

\section{References}

1. Lambolez B, Audinat E, Bochet P, Crepel F, Rossier J (1992) Ampa receptor subunits expressed by single purkinje-cells. Neuron 9 (2):247-258. https://doi.org/10.1016/ 0896-6273(92)90164-9

2. Bochet P, Audinat E, Lambolez B, Crepel F, Rossier J, Iino M, Tsuzuki K, Ozawa S (1994) Subunit composition at the single-cell level explains functional-properties of a glutamategated channel. Neuron 12(2):383-388. https://doi.org/10.1016/0896-6273(94) 90279-8

3. Jonas P, Racca C, Sakmann B, Seeburg PH, Monyer H (1994) Differences in Ca2+ permeability of Ampa-type glutamate-receptor channels in neocortical neurons caused by differential Glur-B subunit expression. Neuron 12(6):1281-1289. https://doi.org/10.1016/ 0896-6273(94)90444-8

4. Tsuzuki K, Lambolez B, Rossier J, Ozawa S (2001) Absolute quantification of AMPA receptor subunit mRNAs in single hippocampal neurons. J Neurochem 77(6):1650-1659. https://doi.org/10.1046/j.1471-4159.2001. 00388.x

5. Lambolez B, Ropert N, Perrais D, Rossier J, Hestrin S (1996) Correlation between kinetics and RNA splicing of alpha-amino-3-hydroxy5-methylisoxazole-4-propionic acid receptors in neocortical neurons. Proc Natl Acad Sci USA 93(5):1797-1802. https://doi.org/10. 1073 /pnas.93.5.1797

6. Angulo MC, Lambolez B, Audinat E, Hestrin S, Rossier J (1997) Subunit composition, kinetic, and permeation properties of AMPA receptors in single neocortical nonpyramidal cells. J Neurosci 17(17):6685-6696

7. Hepp R, Hay YA, Aguado C, Lujan R, Dauphinot L, Potier MC, Nomura S, Poirel O, El Mestikawy S, Lambolez B, Tricoire L (2015) Glutamate receptors of the delta family are widely expressed in the adult brain. Brain
Struct Funct 220(5):2797-2815. https://doi. org/10.1007/s00429-014-0827-4

8. Liss B, Franz O, Sewing $S$, Bruns R, Neuhoff H, Roeper J (2001) Tuning pacemaker frequency of individual dopaminergic neurons by $\mathrm{Kv} 4.3 \mathrm{~L}$ and KChip3.1 transcription. EMBO J 20(20):5715-5724. https:// doi.org/10.1093/emboj/20.20.5715

9. Tricoire L, Pelkey KA, Erkkila BE, Jeffries BW, Yuan XQ, McBain CJ (2011) A blueprint for the spatiotemporal origins of mouse hippocampal interneuron diversity. J Neurosci 31 (30):10948-10970. https://doi.org/10. 1523/Jneurosci.0323-11.2011

10. Cauli B, Audinat E, Lambolez B, Angulo MC, Ropert N, Tsuzuki K, Hestrin S, Rossier J (1997) Molecular and physiological diversity of cortical nonpyramidal cells. J Neurosci 17 (10):3894-3906

11. Karagiannis A, Gallopin T, David C, Battaglia D, Geoffroy H, Rossier J, Hillman EMC, Staiger JF, Cauli B (2009) Classification of NPY-expressing neocortical interneurons. J Neurosci 29(11):3642-3659. https://doi. org/10.1523/Jneurosci.0058-09.2009

12. Perrenoud Q, Rossier J, Geoffroy H, Vitalis T, Gallopin T (2013) Diversity of GABAergic interneurons in layer VIa and VIb of mouse barrel cortex. Cereb Cortex 23(2):423-441. https://doi.org/10.1093/cercor/bhs032

13. Ferezou I, Cauli B, Hill EL, Rossier J, Hamel E, Lambolez B (2002) 5-HT3 receptors mediate serotonergic fast synaptic excitation of neocortical vasoactive intestinal peptide/cholecystokinin interneurons. J Neurosci 22(17):7389-7397

14. Ferezou I, Hill EL, Cauli B, Gibelin N, Kaneko T, Rossier J, Lambolez B (2007) Extensive overlap of mu-opioid and nicotinic sensitivity in cortical interneurons. Cereb Cortex 17(8):1948-1957 
15. Hill EL, Gallopin T, Ferezou I, Cauli B, Rossier J, Schweitzer P, Lambolez B (2007) Functional $\mathrm{CBI}$ receptors are broadly expressed in neocortical GABAergic and glutamatergic neurons. J Neurophysiol 97 (4):2580-2589. https://doi.org/10.1152/jn. 00603.2006

16. Porter JT, Cauli B, Tsuzuki K, Lambolez B, Rossier J, Audinat E (1999) Selective excitation of subtypes of neocortical interneurons by nicotinic receptors. J Neurosci 19 (13):5228-5235

17. Battaglia D, Karagiannis A, Gallopin T, Gutch HW, Cauli B (2013) Beyond the frontiers of neuronal types. Front Neural Circuit 7. ARTN 13 https://doi.org/10.3389/fncir.2013. 00013

18. Pohlkamp T, David C, Cauli B, Gallopin T, Bouche E, Karagiannis A, May P, Herz J, Frotscher M, Staiger JF, Bock HH (2014) Characterization and distribution of Reelinpositive interneuron subtypes in the rat barrel cortex. Cereb Cortex 24(11):3046-3058 . https://doi.org/10.1093/cercor/bht161

19. Cadwell CR, Palasantza A, Jiang XL, Berens P, Deng QL, Yilmaz M, Reimer J, Shen S, Bethge M, Tolias KF, Sandberg R, Tolias AS (2016) Electrophysiological, transcriptomic and morphologic profiling of single neurons using patch-seq. Nat Biotechnol 34 (2):199-203. https://doi.org/10.1038/nbt. 3445

20. Fuzik J, Zeisel A, Mate Z, Calvigioni D, Yanagawa Y, Szabo G, Linnarsson S, Harkany $\mathrm{T}$ (2016) Integration of electrophysiological recordings with single-cell RNA-seq data identifies neuronal subtypes. Nat Biotechnol 34 (2):175-183. https://doi.org/10.1038/nbt. 3443

21. Cauli B, Porter JT, Tsuzuki K, Lambolez B, Rossier J, Quenet B, Audinat E (2000) Classification of fusiform neocortical interneurons based on unsupervised clustering. Proc Natl Acad Sci USA 97(11):6144-6149. https:// doi.org/10.1073/pnas.97.11.6144
640 


\section{Author Queries}

Chapter No.: 10 429758_1_En

\begin{tabular}{|l|l|l|}
\hline Query Refs. & Details Required & Author's response \\
\hline AU1 & $\begin{array}{l}\text { Please check whether the author names and } \\
\text { affiliation are presented correctly. }\end{array}$ & \\
\hline AU2 & $\begin{array}{l}\text { Please check and confirm the presentation of list } \\
\text { levels in throughout the chapter. } \\
\text { dNTP (dATP, dCTP, dGTP, } 7.51 \text { each dNTP } \\
\text { dTTP; final: } 2.5 \mathrm{mM} \text { each) } \\
\text { Random primer (final: } 25 \mathrm{M}) \quad 9.71 \\
\text { dH } 2 \mathrm{O}\end{array}$ & \\
\hline AU3 & $\begin{array}{l}\text { Please check whether the list "1 RNase-free } \mathrm{H}_{2} \mathrm{O} \text { " } \\
\text { is presented correctly here. }\end{array}$ & \\
\hline AU4 & $\begin{array}{l}\text { Please check if edit to sentence starting "In our } \\
\text { experience. ." is okay. }\end{array}$ & \\
\hline
\end{tabular}

